\title{
Influence of E-Counseling Skills on Counseling Self-Efficacy Among E-Counselors in Malaysia
}

\author{
Zaida Nor Zainudin $\mathbb{D}^{D}$, Lee Wei Rong $\mathbb{D}^{D}$, Alia Sarah Asri $\mathbb{D}^{D}$, Yusni Mohamad \\ Yusop ${ }^{D}$, Nor Aniza Ahmad ${ }^{D}$ and Siti Aishah Hassan \\ Universiti Putra Malaysia, Serdang, Selangor, Malaysia
}

\begin{abstract}
Despite the rise in e-counseling services in Malaysia, there is an apparent lack of studies conducted from e-counselors' perspectives on ecounseling features and provisions. The aim of the study is to determine the relationship between e-counseling skills and counseling self-efficacy. This quantitative study applied the descriptive correlational method in order to identify the relationship between e-counseling skills and counseling self-efficacy among e-counselors. The instrumentation involved the use of the Counseling Self-Estimate Inventory (COSE) and a self-constructed questionnaire, the E-Counseling Skills Scale which has undergone validity tests. 233 e-counselors from various institutions in Malaysia were selected using the simple random sampling technique to participate in completing an online survey form. Findings showed that respondents reported a high level of e-counseling skills $(M=4.07, S D=$ $0.60)$ and a moderate level of counseling self-efficacy $(M=4.00, S D=0.67)$. E-counseling skills was positively correlated with counseling self-efficacy $(r=.421, p<.05)$. The multiple regression analysis reported that the subconstruct "goal identification and attainment" of e-counseling skills best predicted counseling self-efficacy $(\beta=.27, t(225)=2.33, p$.05). The findings implied that a higher ability to apply e-counseling skills is linked to higher counseling self-efficacy among e-counselors in Malaysia. This study suggests further improvement and standardization in the counselor education and training policy, specifically in terms of ecounseling interventions for both professional counselors and counseling trainees.
\end{abstract}

Keywords: self-efficacy; e-counseling; e-counselors; counseling skills

\section{Introduction}

The advancement of information technology has significantly impacted a wide range of aspects of human life (Haberstroh et al., 2007). One of the ramifications is on the field of counseling. Access to proper techniques is crucial in providing more creative, entertaining, and innovative guidance and counseling services; these outcomes can be achieved with new technology (Ribbers \& Waringa, 2015). 
As a result, technology-based therapy, also known as e-counseling, has taken root as a viable alternative to traditional counseling methods (Lau et al., 2013; Wong et al., 2018). E-counseling is also widely known as online or Internet counseling (Pollock, 2006), e-therapy, web counseling, cyber counseling, and e-mail therapy (Carlbring et al., 2018; Foon et al., 2020; Mallen \& Vogel, 2005).

The use of technology in the field of counseling is not a new concept. Weizenbaum (1966) was credited with the development of the first e-counseling system, ELIZA, in the 1960s. ELIZA is a computer program that takes a counselor's place in a counseling session in which the client only needs to respond to a computer (Weizenbaum, 1966). After some time, Programmed Logic for Automatic Teaching Operations (PLATO) and Ask Uncle Ezra were introduced as replacements for ELIZA; these two programs, still have their respective webpage forms, as does ELIZA (Zainudin \& Yusop, 2018). Throughout the 1990s, additional e-counseling modalities were developed. E-mail is the most frequently used method of e-counseling then and now (Mejah et al., 2019). Presently, additional technologically-advanced modalities such as telephone counseling, private chatting, text messaging, and video conferencing have become available to many (Zainudin et al., 2021).

In Malaysia, the use of e-counseling services was first introduced in the 1990s to meet the needs of students in the academic setting and overcome the worrying social issues becoming more prevalent among teenagers (Zainudin et al., 2019). According to Zainudin (2006), in the year 2006, 54 Malaysian websites provided e-counseling services. These websites were operated by government agencies, private companies, nongovernmental organizations, and private individuals. It appears that large numbers of local organizations are offering e-counseling services. However, compared to countries such as the United States and Japan, ecounseling services are considered a new phenomenon in Malaysia. Nevertheless, it is a rapidly expanding phenomenon, and we must consider it one of the technological outcomes.

The amount of studies done on e-counseling in Malaysia is still limited. According to Zamani et al. (2010) and Mejah et al. (2020), even though Malaysian counselors are positive about e-counseling services, they still prefer face-to-face counseling or traditional counseling over e-counseling. The difficulties associated with implementing counseling skills in e-counseling are one of the reasons that counselors avoid e-counseling. Foon et al. (2020) asserted that the primary reason counselors refuse to use e-counseling is the lack of nonverbal skills and confidence in carrying out the e-counseling task. Thus, the purpose of this study is to investigate the counseling skills used in e-counseling and to ascertain the relationship between counseling skills and self-efficacy in counseling. At the end of this study, the findings can be used as a review to prepare counselors for ecounseling training. 


\section{Literature Review}

\subsection{E-Counseling Skills}

In this study, the term "e-counseling skills" refers to the counseling skills that ecounselors employ during an e-counseling session. There are a few legitimate concerns regarding e-counselors' skill level in their e-counseling practices. This is due to the fact that counseling skills are the ultimate weapon a counselor can use in a counseling session. Counseling skills assist the counselors in guiding the counseling process and their client in developing and making changes (Erlina Yaumas et al., 2018; Richards \& Viganó, 2013). Nonverbal communication skills are examples of counseling skills.

One of the main concerns is whether the counseling skills demonstrated in a faceto-face counseling session can be transferred to an e-counseling environment (Mattison, 2012). Theoretically, the transfer of most skills is possible between counseling modalities. The abilities to question, paraphrase, build rapport, and empathize are some of the counseling skills that are ready to be used in an online environment (Dowling \& Rickwood, 2014). However, the reality is that some of the skills required for face-to-face counseling are not transferable to e-counseling (Holmes \& Kozlowski, 2016). For instance, the reflection of feelings and nonverbal communication will be difficult to incorporate into some forms of e-counseling, such as e-mail counseling or text counseling. E-counselors can only make assumptions about the clients' feelings based on the text messages. As for nonverbal behaviors, they are as important as verbal messages when it comes to communication (Highlen \& Hill, 1984; Ivey \& Ivey, 2007). The lack of nonverbal behavior in e-counseling may lead counselors to experience feelings of uneasiness because they are unable to interpret their clients' body language or observe how a message is being received (Ballesteros \& Hilliard, 2016; Trepal et al., 2007). During a session, this unease can cause the therapeutic relationship to deteriorate (Ballesteros \& Hilliard, 2016; Manhal-Baugus, 2001). The absence of nonverbal information in some e-counseling situations makes it necessary to employ a unique set of skills when interacting in this environment (Trepal et al., 2007). Therefore, e-counselors require proper training to increase their confidence in conducting accurate assessments without using body language during ecounseling sessions (Foon et al., 2020).

According to some e-counseling feedback received, clients expressed appreciation for the counselor's use of various skills to facilitate the e-counseling process (Lewis et al., 2003). As a result, the researchers are interested in investigating and determining the counseling skills that e-counselors apply.

\subsection{Counseling Self-Efficacy}

Self-efficacy is defined as individuals' level of confidence regarding their capabilities to carry out the desired action or the given tasks (Bandura, 1993). According to Bandura's (1997) social cognitive theory, confidence is critical in a counselor's ability to apply counseling skills. Hence, self-efficacy in counseling refers to an individual's confidence about their ability to provide effective counseling (Larson \& Daniels, 1998). Counseling self-efficacy applies to counselors conducting counseling-related activities such as counseling sessions 
and development programs, regardless of their qualification, years of expertise, or counseling skills and techniques. Studies have demonstrated that believing in one's abilities is essential in maintaining acceptable counseling performance (Bandura, 1982; Haktanir, 2020). According to the self-efficacy theory, subject knowledge, appropriate application of required skills, and belief in one's own ability to perform skills successfully are the keys to a person using the skills successfully (Barnes, 2004; Hill et al., 2016).

In order to gain self-efficacy, one must have first-hand experience of actual performance and achievement, be in a stimulating atmosphere, and have positive beliefs about one's own capabilities (Bandura, 1997). Confidence and sufficient preparation skills that novice counselors lack will be developed as they get more experience through actual counseling sessions or practicum (Goreczny et al., 2015, Lent et al., 2006). Counselors with a higher counseling education, more successful experience in practicing counseling, and more accumulated hours of supervision have been found to have stronger self-efficacy than counselors with lower education levels and knowledge (Larson et al., 1992; Ooi et al., 2017). As a result, the researchers are interested in finding out whether the counseling skills of Malaysian e-counseling practitioners' will affect their self-efficacy.

2.3 The Relationship Between Counseling Skills and Counseling Self-Efficacy As previously indicated, practical counseling skills are essential in a counseling session. In order to conduct a counseling session, the counselor needs to employ counseling skills to assist their clients in resolving the latter's concerns. For a counselor to perform well in a counseling session, confidence is required (Larson \& Daniels, 1998). To apply their counseling skills with confidence in the counseling session, counselors must have self-efficacy. The relationship between counseling skills and counseling self-efficacy is explored in the following review of past studies.

Several studies on counseling self-efficacy have been conducted and addressed, with a few variables such as multicultural competence, counselor performance, and training programs being discussed in more detail (Harun et al., 2014; Holcomb-McCoy et al., 2009; Kiralp, 2015). Self-efficacy is derived from four sources according to the social cognitive theory: mastery experience; social persuasion; vicarious learning; and physiological and anxiety states (Ooi et al., 2017). The majority of the studies' findings on counseling skills and counseling self-efficacy were associated with mastery experience and vicarious learning.

One of the earliest studies by Johnson et al. (1989) aimed to investigate the relationship between counseling self-efficacy and counseling student performance in the context of increased counseling skills training. Fifty master's degree counseling students participated in the study which reported that training increases the counseling self-efficacy of the students. Moreover, despite the weak relationship linking counseling skills to self-efficacy, the study found that participants who have high levels of self-efficacy in counseling perform better in a counseling skill test (Johnson et al., 1989). The results corroborated Hill et al.'s 
(2016) findings stating that students' helping skills as lay counselors improved at the end of the semester as their self-efficacy increased.

Urbani et al. (2002) identified a relationship between counseling skills and counseling self-efficacy. The objective was to ascertain the effect of the Skilled Counselor Training Model (SCTM) on the development of counseling skills and self-efficacy among 61 participating counselor trainees. The results showed that the SCTM significantly improves the counseling skills of the participants. The SCTM was also reported to increase counselor self-efficacy and counseling practice effectiveness (Urbani et al., 2002). Goreczny et al. (2015) discovered that practicing counselors have a higher self-efficacy in counseling at the end of their practice. This is because their knowledge and skills have increased in comparison to those at the start of the learning process.

Likewise, Larson and Daniels (1998) concluded that the mastery of counseling skills and appropriate modeling of counseling skills may help in increasing counseling self-efficacy, resultantly reducing anxiety in counselors. This result is similar to Melchert et al.'s (1996) on students' level of training and clinical experience associated with higher self-efficacy of their counseling skills. In Malaysia, Ooi et al. (2017) discovered a strong correlation between mastery experience and counselor self-efficacy.

In relation to self-efficacy, Greason and Cashwell (2009) were interested in testing first, the relationship between mindfulness and self-efficacy in counseling and second, the mediating roles of attention and empathy. The findings indicated that providing opportunities for students to practice, learn, and master multiple counseling skills is an effective way to boost their self-efficacy.

Larson et al. (1999) conducted several types of studies on counseling self-efficacy. The microskills of a counselor trainee will improve as a result of participating in role-playing sessions, which will also indirectly improve their counseling selfefficacy (Larson et al., 1992; Larson et al., 1999). Role-playing is similar to real-life situations in that it provides successful experiences that assist counselor trainees in developing confidence.

Easton et al. (2008) found more specific results on counseling skills and counseling self-efficacy. The study aimed to explore the relationship between emotional intelligence and counseling self-efficacy. A total of 140 counselors and counselor trainees were participants in the study. The result indicated that professional counselors perceive higher levels of emotional intelligence than counseling students to solve problems. Besides, self-efficacy is essential because it increases the confidence of the counselor, which contributes to the development of problem-solving and decision-making abilities during the counseling session (Easton et al., 2008). Following the review of previous studies, the majority of them linking counseling skills and counseling self-efficacy among e-counselors were not conducted directly. There have also been very few studies in a Malaysian context discussing this topic despite the prevalence and expansion of e-counseling services nowadays. Therefore, our study is aimed to: 
1. Identify the level of e-counseling skills and counseling self-efficacy among e-counselors in Malaysia.

2. Identify whether there is a significant relationship between ecounseling skills and counseling self-efficacy among e-counselors in Malaysia.

3. Identify the influence of e-counseling skills' subconstructs on counseling self-efficacy among e-counselors in Malaysia.

\section{Method}

\subsection{Study Design}

A quantitative correlational study was applied to determine the level of ecounseling skills and counseling self-efficacy; the relationship linking the two variables; and the influence of e-counseling skills on counseling self-efficacy.

\subsection{Study Sample}

From a total of 750 e-counselors from various institutions in Malaysia identified and contacted for participation in this study, 233 responses were successfully collected. The male participants numbered 52, while female participants totaled 181. Each participant belonged to one of four age groups: 51 participants were between the ages of 23 and 29; 53 were between the ages of 30 and 35; 45 were between the ages of 36 and 40; and 84 were aged 41 and above. An online survey form containing the questionnaire was used to collect responses from the study participants. A simple random sampling procedure was used to select the participants of this study.

\subsection{Study Instruments}

Demographic information

Seven items were included in the survey's demographic section. The items covered the counselors' general information such as gender, age group, ethnic group, education level, counseling experiences, registration status, and licensure status.

\section{Counseling Self-Estimate Inventory (COSE)}

The COSE was adapted from Larson et al. (1992). The inventory consisted of a total of 37 items divided into five subsections. The five subsections were "microskills" (12 items), "process" (10 items), "difficult client behaviors" (seven items), "cultural competence" (four items), and "awareness of values" (four items).

A 6-point Likert scale was used to score the 37 items. The items on the Likert scale were designed to determine the level of participants' counseling self-efficacy. Questionnaires using the Likert scale were graded as follows, from a scale of 1 to 6: "Strongly disagree", "Moderately disagree", "Slightly disagree", "Slightly agree", "Moderately agree", and "Strongly agree". Nineteen items in the inventory were negative items. The scores were recoded when running the analysis. The mean score was used to determine the e-counselors' level of counseling self-efficacy. The scoring marks were categorized into three levels: high, moderate, and low. A mean score between 4.21 and 6.00 is considered high; 
between 2.53 and 4.21 is considered moderate; and between 1.00 and 2.53 is considered low.

The inventory utilized in this study was bilingual in nature. The original language was English, which was then translated into Malay. To determine the scale's reliability, a pilot test was conducted. The Cronbach's alpha value for the items was .93, indicating that the items were reliable. An earlier study by Larson et al. (1992) reported a COSE with good internal consistency with a Cronbach's alpha of .93 and test-retest reliability of .87 . Validity tests and back-translation were conducted to ascertain validity. The translation was reviewed and validated by a panel of experts.

\section{E-Counseling Skills Scale}

The e-counseling skills scale, a 34-item scale, was divided into seven subconstructs. Subconstruct 1 focused on "structuring skills and rapportbuilding", which consisted of three items dealing with structuring and building relationships. Subconstruct 2 was devoted to "exploration skill", containing five related items. Subconstruct 3 was concerned with "communication skill" consisting of 13 items, which included all of the fundamental communication skills strategies and tactics. Subconstruct 4 was devoted to "goal identification and attainment" with a total of four items. Subconstruct 5 was dedicated to "problemsolving skill" consisting of three items related to this skill. Subconstruct 6 was on "empathy skill" and consisted of three items. The final subconstruct, 7, was "multicultural skill" represented by three items related to multicultural competence.

A 5-point Likert scale was used to score the 34 item scale. The items on the Likert scale were designed to determine the level of e-counselors' e-counseling skills application. Questionnaires using the Likert scale were graded as follows from 1 to 5: "Strongly disagree", "Disagree", "Neither", "Agree", and "Strongly agree". The mean score was used to determine e-counselors' level of e-counseling skills application. The scoring marks were categorized into three levels: high, moderate, and low. A mean score ranging from 3.68 to 5.00 is considered high; from 2.34 to 3.68 is considered moderate; and from 1 to 2.34 is considered low.

This e-counseling skills scale employed a dual-language approach. The languages used were Malay and English. A pilot test was conducted to determine the scale's reliability. The Cronbach's alpha value reported was .98, implying that the items were reliable. Validity was achieved through a review of existing studies and was confirmed through item evaluation from a panel of two experts in the Guidance and Counseling program.

\subsection{Data Analysis}

The descriptive analysis, Pearson's correlation, and multiple regression techniques were used in this study, aided by the SPSS version 26 software. The levels of e-counseling skill and counseling self-efficacy were determined using descriptive analysis. The Pearson's correlation analysis was conducted to ascertain the relationship between e-counseling skills and self-efficacy in 
counseling. The multiple regression analysis was used to determine which subconstructs of e-counseling skills best predicted self-efficacy in counseling among the e-counselors.

\section{Results and Discussion}

\subsection{Respondents' Demographic Profile}

Table 1 shows the distribution of the respondents based on the demographic variables. Females dominated the sample by more than triple the male sample. It could also be observed that most respondents, comprising more than a quarter, fell into the range of 41 years old and above. Chinese and Indians covered similar portions among the respondents with $6.4 \%$ and $6.0 \%$ respondents respectively. Moreover, as expected, the higher the education level, the lower the percentage of respondents.

As for the years of counseling experience, the majority of respondents $(37.8 \%)$ were reported to have between 6 and 15 years of experience, closely followed by those with five years or fewer (36.5\%). In terms of the counselors' registration and licensure statuses, most were registered counselors and licensed counselors (75.5\% and $69.1 \%$ respectively), implying their recognition by national counseling authorities.

Table 1: Respondents' demographic profile

\begin{tabular}{lcc}
\hline \multicolumn{1}{c}{ Demographic variables } & $f$ & $\%$ \\
\hline Gender & 52 & 22.3 \\
Male & 181 & 77.7 \\
Female & & \\
Age & 51 & 21.9 \\
23-29 years old & 53 & 22.7 \\
30-35 years old & 45 & 19.3 \\
36-40 years old & 84 & 36.1 \\
41 years old and above & & \\
Ethnicity & 171 & 73.4 \\
Malay & 15 & 6.4 \\
Chinese & 14 & 6.0 \\
Indian & 33 & 14.2 \\
Others & & \\
Education Level & 124 & 53.2 \\
Bachelor's degree & 96 & 41.2 \\
Master's degree & 13 & 5.6 \\
Doctor of philosophy & & \\
Counseling Experience & 85 & 36.5 \\
5 years and below & 88 & 37.8 \\
6-15 years & 58 & 24.9 \\
16-30 years & 2 & 0.9 \\
31 years and above & & \\
Registered Counselor & 176 & 75.5 \\
Yes & 57 & 24.5 \\
No & & 69.1 \\
Licensed Counselor & 161 & 30.9 \\
Yes & 72 & \\
No & & \\
\hline
\end{tabular}




\subsection{Level of E-Counseling Skills}

The descriptive analysis reported that item 4 ("Although not face-to-face, I am able to ask open-ended questions to explore client's concerns"), item 3 ("Although not face-to-face, I am able to integrate informed consent into the initial session with client"), and item 2 ("Although not face-to-face, I am able to structure during the initial session with client") had the highest mean scores of 4.37, 4.36, and 4.31 respectively. This indicates that e-counselors apply structuring and rapportbuilding skills the most in e-counseling sessions. The skills applied were similar to the skills in face-to-face counseling (Asri et al., 2020). On the other hand, the lowest mean reported was for item 9, "Although not face-to-face, I am able to show congruence between verbal and nonverbal behaviors in the session with the client" with a mean score of 3.64. This finding demonstrates that e-counselors continue to have concerns and issues with nonverbal skills, which is always a point of contention in e-counseling (Salleh et al., 2015; Richards \& Viganó, 2013; Zamani et al., 2010).

Table 2 shows the overall level of counseling skills applied by the e-counselors which is high. The mean score $(M=4.07)$ fell between 3.68 and 5.00, hence the high e-counseling skill application. For the subconstructs, "structuring skill and rapport-building" reported the highest mean score of 4.31, showing a high level of e-counseling application. This was followed by the subconstruct "empathy skill" which had a mean score of 4.21; also considered high application. Following this were "goal identification and attainment" $(M=4.11)$, "multicultural skill" $(M$ = 4.09), "problem-solving skill" $(M=4.04)$, "communication skill" $(M=4.01)$, and lastly, "exploration skill" $(M=3.94)$.

Table 2: Level of e-counseling skills and subconstructs

\begin{tabular}{lccc}
\hline \multicolumn{1}{c}{ E-counseling skills and subconstructs } & $\boldsymbol{M}$ & SD & Level \\
\hline Structuring skill and rapport-building & 4.31 & 0.66 & High \\
Exploration skill & 3.94 & 0.68 & High \\
Communication skill & 4.01 & 0.63 & High \\
Goal identification and attainment & 4.11 & 0.64 & High \\
Problem-solving skill & 4.04 & 0.69 & High \\
Empathy skill & 4.21 & 0.67 & High \\
Multicultural skill & 4.09 & 0.67 & High \\
E-counseling skills application (overall) & 4.07 & 0.60 & High \\
\hline
\end{tabular}

The e-counselors have demonstrated that they employ all of their counseling skills during their e-counseling session. All of the subconstructs are also of high level in terms of application, particularly "structuring skills and rapport-building". The least applied subconstruct was the "exploration skill". These findings are consistent with Asri et al.'s (2020) which reported the rapport-building skill as the most applied counseling skill by different samples of e-counseling practitioners. The same study noted that it is especially important for e-counselors to build a good rapport with clients, most particularly during the initial phase of counseling sessions prior to discussing goals and intervention plans. This discovery on rapport-building is also parallel to a study done by Barnett (2005). Barnett (2005) concluded that e-counseling is more oriented toward an informative approach to 
problem-solving, with the exploration portion of the session being reduced. Besides, the high level of application of counseling skills indicates that an ecounselor possesses strong counseling competency. According to the findings of Sawyer et al. (2013), there is a statistically significant relationship between counseling skills and counselor competency. Additionally, while it is important to build a successful counseling relationship, it is necessary to master the fundamental communication skills (Setiyowati et al., 2019). Adigwe and Okoro (2016) also stated that counseling skills are a critical component of effective counseling practices.

\subsection{Level of Counseling Self-Efficacy}

All of the counseling self-efficacy items were analyzed to determine their mean score and standard deviation. The highest mean score $(M=4.89)$ belonged to item 29, "I am confident that I will know when to use open or close-ended probes, and that these probes will reflect the concerns of the client and not be trivial". According to Mallen et al. (2011), open and closed questions are the most frequently used interventions by online counselors. In contrast, the item with the lowest mean score $(M=2.91)$ was item 16 , "I am afraid that I may not understand and properly determine probable meanings of the client's nonverbal behaviors". This lowest mean score result is similar to previous studies showing that ecounselors are not confident with nonverbal behavior (Ballesteros \& Hilliard, 2016; Foon et al., 2020). Item $9(M=4.78)$ demonstrates the level of e-counselors' confidence in handling e-counseling with the statement "I feel confident that I will appear competent and earn the respect of my client". The mean score of item 9 was almost identical to the highest mean score, which signifies that e-counselors in Malaysia are confident in their ability to handle e-counseling.

Table 3 shows the level of counseling self-efficacy. The overall self-efficacy level of the e-counselors is moderate $(M=4.00)$. "Microskills" $(M=4.71)$ was reported as the highest-scoring subconstruct in counseling self-efficacy. This subconstruct was followed by "cultural competence" $(M=4.05)$, "awareness of values" $(M=$ 3.99), "difficult client behaviors" $(M=3.75)$, and finally, "process" $(M=3.22)$; all reporting moderate levels.

Table 3: Level of counseling self-efficacy

\begin{tabular}{lccc}
\hline \multicolumn{1}{c}{$\begin{array}{c}\text { Counseling self-efficacy and } \\
\text { subconstructs }\end{array}$} & $\boldsymbol{M}$ & SD & Level \\
\hline Microskills & 4.71 & 0.77 & High \\
Process & 3.22 & 1.19 & Moderate \\
Difficult client behaviors & 3.75 & 0.712 & Moderate \\
Cultural competence & 4.05 & 0.72 & Moderate \\
Awareness of values & 3.99 & 1.02 & Moderate \\
Counseling self-efficacy (overall) & 4.00 & 0.67 & Moderate \\
\hline
\end{tabular}

The results show a similarity with the Malaysian school counselors' counseling self-efficacy level, which according to Yusof et al. (2017), is moderate. Counseling self-efficacy is a significant predictor of work performance and helps counselors face difficult or stressful situations (Gonzalez \& Johnston, 2009; Larson \& Daniels, 1998; Skaalvik \& Skaalvik, 2007). As a result, it is critical to maintaining a 
consistent focus on improving counseling efficacy among e-counselors. A higher level of self-efficacy indicates that they are more confident in their ability to complete a specific task. If individuals are confident in their abilities, they will complete the task effectively (Larson \& Daniels, 1998).

\subsection{Relationship Between E-Counseling Skills and Counseling Self-Efficacy}

Table 4 presents the Pearson's correlation analysis test between e-counseling skills $(M=4.07, S D=0.60)$ and counseling self-efficacy $(M=4.00, S D=0.67)$. The overall result indicates a significant positive correlation between e-counseling skills and counseling self-efficacy $(r=.421, p=.000)$. According to Guildford's rule of thumb, the overall relationship is considered a moderate relationship. As for the individual subconstructs of e-counseling skills, all of them report a low significant positive correlation with counseling self-efficacy except the subconstruct "goal identification and attainment". However, the correlation coefficient of "structuring and rapport-building" had a probability value of .001 unlike the other subconstructs $(p=.000)$ with the same relationship. The one with the highest correlation coefficient, "goal identification and attainment", shows a moderate significant positive relationship with counseling self-efficacy $(r=.418, p=.000)$.

Table 4: Correlation between e-counseling skills and counseling self-efficacy

\begin{tabular}{lcc}
\hline Variable & $\begin{array}{c}\text { Counseling } \\
\text { self-efficacy }\end{array}$ & $\begin{array}{c}\text { Result of Pearson's } \\
\text { correlation }\end{array}$ \\
\hline Structuring skill and rapport-building & $.222^{* *}$ & Low significant positive \\
Exploration skill & $.340^{* *}$ & Low significant positive \\
Communication skill & $.398^{* *}$ & Low significant positive \\
Goal identification and attainment & $.418^{* *}$ & $\begin{array}{c}\text { Moderate significant } \\
\text { positive }\end{array}$ \\
Problem-solving skill & $.349^{* *}$ & Low significant positive \\
Empathy skill & $.368^{* *}$ & Low significant positive \\
Multicultural skill & $.339^{* *}$ & Low significant positive \\
E-counseling skill (overall) & $.421^{* *}$ & $\begin{array}{c}\text { Moderate significant } \\
\text { positive }\end{array}$ \\
\hline
\end{tabular}

${ }^{* *}$ Correlation is significant at the 0.01 level (two-tailed).

The findings are consistent with those of past studies discovering that a counseling skill acquired through counseling training is correlated with counseling self-efficacy in the long run. When counselors' self-efficacy in counseling is high, they will be more efficient in their counseling skills performance (Greason \& Cashwell, 2009; Johnson et al., 1989; Larson \& Daniels, 1998; Larson et al., 1999; Urbani et al., 2002). This is due to the fact that they will have a high level of confidence in their ability to perform the skill during the counseling session. Counselors, whether trainees or professionals, must have confidence in their abilities. In one study, counseling self-efficacy was linked to counseling anxiety (Goreczny et al., 2015). Counselors who have a high sense of self-efficacy will have a more positive self-perception of their abilities. The increased self-awareness of even their weaknesses will assist them in reducing their anxiety during the counseling session (Goreczny et al., 2015). The development of counseling skills and the development of counseling self-efficacy are therefore closely related. 


\subsection{Influence of E-Counseling Skills on Counseling Self-Efficacy}

Table 5 shows the result of the multiple regression test for the predictors of counseling self-efficacy. Results indicate that "goal identification and attainment" has significantly predicted counseling self-efficacy $(\beta=.27, t(225)=2.33, p<.05)$. On the contrary, other subconstructs did not significantly predict counseling selfefficacy. Together, all subconstructs explained a significant proportion of variance in counseling self-efficacy $\left(\mathrm{R}^{2}=.452, F(7,225)=8.251, p=.000\right)$.

Table 5: Result of regression analysis on counseling self-efficacy

\begin{tabular}{lccccc}
\hline Factors & $\boldsymbol{b}$ & $S E$ & $\beta$ & $\boldsymbol{t}$ & $\boldsymbol{p}$ \\
\hline Constant & 1.96 & .32 & & 6.19 & 2.78 \\
Structuring skill and rapport-building & -.09 & .08 & -.09 & -1.10 & .27 \\
Exploration skill & .02 & .10 & .02 & .19 & .85 \\
Communication skill & .08 & .15 & .07 & .50 & .62 \\
Goal identification and attainment & .28 & .12 & .27 & 2.33 & .02 \\
Problem-solving skill & .04 & .09 & .04 & .44 & .66 \\
Empathy skill & .15 & .08 & .15 & 1.71 & .09 \\
Multicultural skill & .03 & .09 & .02 & .28 & .78 \\
\hline
\end{tabular}

The findings are the first regarding predictors of counseling self-efficacy. Previous studies only demonstrated that problem-solving and decision-making skills will impact counseling self-efficacy (Easton et al., 2008). However, our study found that "problem-solving skill" is not a predictor of counseling self-efficacy. The only difference between our study and the existing studies is the counseling modality; traditional counseling was the modality in most of the existing studies, as opposed to e-counseling in our study. Future studies are required to determine the reason to support this finding on self-efficacy predictors.

\section{Conclusion}

In conclusion, this study found that e-counselors in Malaysia demonstrate a high level of e-counseling skills in their e-counseling sessions. Their counseling selfefficacy is at a moderate level, indicating that they are confident in their ability to provide e-counseling services. Therefore, e-counseling should be applicable in Malaysia. E-counseling skills were also reported to be significantly and positively correlated with counseling self-efficacy. Skills competency and self-efficacy are important factors in boosting counselors' self-efficacy. The greater the number of skills learned, the greater one's sense of self-efficacy. The analysis also revealed that the subconstruct of e-counseling skills "goal identification and attainment" best-predicted counseling self-efficacy. Consequently, counselor training can identify which skills are important while simultaneously assisting trainees in increasing their self-efficacy.

\section{Implication and Recommendation}

This study adds to the body of knowledge on counselors' personal and professional development. A better understanding of the relationship between ecounseling skills and counseling self-efficacy in Malaysia is provided. Since a search of journal databases yields few studies on this topic among Malaysian ecounselors, interested researchers will find the results of this study valuable. 
Furthermore, the study's findings may be used to create an overview of the ecounseling service in Malaysia. Understanding counseling skills and the level of confidence a counselor has in carrying out an e-counseling session will assist in alleviating some of the concerns about the limitations of e-counseling. In reality, the strategies and techniques used in face-to-face counseling and e-counseling are nearly identical.

Moreover, the findings can be used as a training guideline in the field of counseling in Malaysia. It is possible that e-counseling skills can predict the level of counseling self-efficacy. This prediction can provide guidance to counseling educators on how to increase their students' competence and confidence level through the counseling skills class. In addition, counseling educators' experiences are significant and valuable. The counselors' experiences, despite being secondhand, will aid in the development of counseling self-efficacy in the counselor trainees.

This study discovered the levels of e-counseling skills and counseling self-efficacy that participants possessed; the relationship between both variables; and a predictor of self-efficacy. There was, however, no attempt to determine whether counseling self-efficacy was associated with e-counselor performance. Aside from that, a predictor of e-counseling skills should be identified in a future study. The comparison between skills in e-counseling and face-to-face counseling modalities can be made in future studies to see whether there is a difference in counseling self-efficacy. The counselors' background, including their family's socioeconomic status, the university where they earned their first degree, and their counseling experiences, should be considered in future studies.

\section{Limitations}

There are several limitations to this study. As a starting point, the study does not include information about the counselors' e-counseling experiences, which may or may not have a significant impact on their counseling self-efficacy in the context of e-counseling. Furthermore, our study makes no distinction between the different types of e-counseling (e-mail, online chatroom, video conference, and others). Different modalities will necessitate the development of different types of skills. As a result, the outcome of the e-counseling session may be adversely affected.

\section{Acknowledgments}

This study has been granted funds from Fundamental Research Grant Scheme (FRGS) by Ministry of Higher Education (MOHE) (FRGS/1/2018/SS05/UPM/02/2).

\section{References}

Adigwe, P., \& Okoro, E. (2016). Human Communication and Effective Interpersonal Relationships: An Analysis of Client Counseling and Emotional Stability. International Journal of Economics \& Management Sciences, 05(03), 3-6. https://doi.org/10.4172/2162-6359.1000336 
Asri, A. S., Zainudin, Z. N., Othman, W. N. W., Hassan, S. A., Ahmad, N. A., Talib, M. A., \& Yusop, Y. M. (2020). E-counselling process and skills: A literature review. Journal of Critical Reviews, 7(13), 629-643. http:/ / doi.org/10.31838/jcr.07.13.110

Ballesteros, J. L., \& Hilliard, R. C. (2016). U.S.Based Latina/O College Students' Attitudes toward Online Counseling. Int $J$ Adv Counselling, 38, 269-285. https://doi.org/10.1007/s10447-016-9271-x

Bandura, A. (1993). Perceived self-efficacy in cognitive development and functioning. Educational Psychologist, 28(2), 117-148. https://doi.org/10.1207/s15326985ep2802_3

Bandura, A. (1997). Self-efficacy: The exercise of control. Freeman.

Bandura, A. (1982). Self-efficacy mechanism in human agency. American Psychologist, 37, 122-147. https:/ / doi.org/10.1037/0003-066X.37.2.122

Barnes, K. L. (2004). Applying self-efficacy theory to counselor training and supervision: A comparison of two approaches. Counselor Education and Supervision, 44(1), 5669. https:/ / doi.org/10.1002/j.1556-6978.2004.tb01860.x

Barnett, J. E. (2005). Online Counseling: New Entity, New Challenges. The Counseling Psychologist, 33(6), 872-880. https:/ / doi.org/10.1177/0011000005279961

Carlbring, Per., Gerhard, A., Pim, C., Heleen, R., \& Erik, H. (2018). Internet-based vs. faceto-face cognitive behavior therapy for psychiatric and somatic disorders: An updated systematic review and meta-analysis. Cognitive Behavior Therapy, 47(1), 118. https:/ / doi.org/10.1080/16506073.2017.1401115

Dowling, M. J., \& Rickwood, D. J. (2014). Experiences of counselors providing online chat counseling to young people. Australian Journal of Guidance and Counseling, 24(2), 183-196. https:/ / doi.org/10.1017/jgc.2013.28

Easton, C., Martin Jr., W., \& Wilson, S. (2008). Emotional intelligence and implications for counseling self-efficacy: Phase II. Counselor Education and Supervision, 47, 218-232. https://doi.org/10.1002/j.1556-6978.2008.tb00053.x

Erlina Yaumas, N., Syafril, S., Mohd Noor, N., Mahmud, Z., Umar, J., Wekke, I., \& Rahayu, T. (2018). The Importance of Counseling Basic Skills for the Counselors. International Journal of Pure and Applied Mathematics, 119, 1195-1207.

Foon, L. W., Zainudin, Z. N., Yusop, Y. M., Wan Othman, W. N. (2020). E-counseling: The intention, motivation and deterrent among school counselors. Universal Journal of Educational Research, 8(3C), 44-51. https://doi.org/10.13189/ujer.2020.081605

Goreczny, A. J., Hamilton, D., Lubinski, L., \& Pasquinelli, M. (2015). Exploration of counselor self-efficacy across academic training. Clinical Supervisor, 34(1), 78-97. https://doi.org/10.1080/07325223.2015.1012916

Greason, P. B., \& Cashwell, C. S. (2009). Counselor preparation mindfulness and counseling self-efficacy: The mediating role of attention and empathy. Counselor Education and Supervision, 49(1), 2-19. https://doi.org/10.1002/j.15566978.2009.tb00083.x

Haberstroh, S., Duffey, T., Evans, M., Gee, R., \& Trepal, H. (2007). The experience of online counseling. Journal of Mental Health Counseling, 29(3), 269-282. https://doi.org/10.17744/mehc.29.3.j344651261w357v2

Haktanir, A. (2020) A comparison of counselling self-efficacy among international and domestic counselling students. Journal of Psychologists and Counsellors in Schools, 110. https://doi.org/10.1017/jgc.2020.19

Harun, M. M., \& Kadir, R. A. (2014). Self-Perceived Multicultural Counseling Self-Efficacy Levels Among School Counseling Teachers. Journal of Human Capital Development, 7(2), 97-113. Journal of Human Capital Development (JHCD). https://journal.utem.edu.my/index.php/jhcd/article/view/2134/1281 
Highlen, P. S., \& Hill, C. E. (1984). Factors affecting client change in counseling. Handbook of counseling psychology (4 $4^{\text {th }}$ ed.). Wiley.

Hill, C. E., Anderson, T., Kline, K., McClintock, A., Cranston, S., McCarrick, S., Petrarca, A., Himawan, L., Pérez-Rojas, A. E., Bhatia, A., Gupta, S., \& Gregor, M. (2016). Helping skills training for undergraduate students: Who should we select and train? $\Psi$. The Counseling Psychologist, 44(1), 50-77. https://doi.org/10.1177/0011000015613142

Holcomb-Mccoy, C., Ileana, G., \& Georgina, J. (2009). School counselor dispositions as predictors of data usage. Professional School Counseling, 12(5). https:// doi.org/10.1177/2156759x0901200504

Holmes, C., \& Kozlowski, K. (2016). A pilot study of online group leadership skills: Perceived usage and difficulty level. Journal of Counselor Practice, 7(2), 61-77. https://10.22229/gkp070201.

Ivey, A. E., \& Ivey, M. B. (2007). Intentional interviewing and counseling: Facilitating client development in a multicultural society ( $6^{\text {th }}$ ed.). Brooks/Cole

Johnson, E., Baker, S. B., Kopala, M., Kiselica, M. S., \& Thopmson, E. C. (1989). Counseling self-efficacy and counseling competence in prepracticum training. Counselor Education and Supervision, 28(3), 205-218. https://doi.org/10.1002/j.15566978.1989.tb01109.x

Kiralp, F. S. S. (2015). Do courses taken from psychological counseling departments affect the trainee counselor's self-efficacy? Procedia Social and Behavioral Sciences, 205, 637-641. https://doi.org/10.1016/j.sbspro.2015.09.100

Larson, L. M., Clark, M. P., Wesely, L. H., Koraleski, S. F., Daniels, J. A., \& Smith, P. L. (1999). Videos versus role plays to increase counseling self-efficacy in prepractica trainess. Counselor Education and Supervision, 38(4), 237-248. https://doi.org/10.1002/j.1556-6978.1999.tb00574.x

Larson, L. M., \& Daniels, J. A. (1998). Review of the counseling self-efficacy literature. The Counseling Psychologist, 26(2), 179-218. https://doi.org/10.1177/0011000098262001

Larson, L. M., Suzuki, L. A., Gillespie, K. N., Potenza, M. T., Bechtel, M. A., \& Toulouse, A. L. (1992). Development and validation of the Counseling Self-Estimate Inventory. Journal of Counseling Psychology, 39, 105-120. https://doi.org/10.1037/0022-0167.39.1.105

Lau, P. L., Jaladin, R.A.M., \& Abdullah, S. H. (2013). Understanding the two sides of online counseling and their ethical and legal ramifications. Procedia Social and Behavioral Sciences, 103, 1243-1251. https://doi.org/10.1016/j.sbspro.2013.10.453

Lent, R. W., Hoffman, M. A., Hill, C. E., Treistman, D., Mount, M., \& Singley, D. (2006). Client-specific counselor self-efficacy in novice counselors: relation to perceptions of session quality. Journal of Counseling Psychology, 53(4), 453-463. https://doi.org/10.1037/0022-0167.53.4.453.

Lewis, J., Coursol, D., \& Wahl, K. H. (2004). Researching the cybercounseling process: A study of the client and counselor experience. Cybercounseling and Cyberlearning: An Encore, 307-325.Eric http://eric.ed.gov/ERICWebPortal/recordDetail?accno=ED481145

Mallen, M., Jenkins, I., Vogel, D., \& Day, S. (2011). Online counselling: An initial examination of the process in a synchronous chat environment. Counselling and Psychotherapy $\quad$ Research, 220-227. https:// doi.org/10.1080/14733145.2010.486865

Mallen, M. J., \& Vogel, D. L. (2016). Introduction to the major contribution. The Counseling Psychologist, 33(6), 761-775. https://doi.org/10.1177/0011000005278623 
Manhal-Baugus (2001). E-therapy: Practical, ethical, and legal issues. CyberPsychology $\mathcal{E}$ Behavior, 4(5), 551-563. https://doi.org/10.1089/109493101753235142

Mattison, M. (2012). Social work practice in the digital age: Therapeutic email as a direct practice methodology. Social Work, 57(3), 249-258. https://doi.org/10.1093/SW/SWS021

Mejah, H., Bakar, A. Y. A., \& Amat, S. (2019). Online counseling as an alternative of new millennial helping services. International Journal of Academic Research in Business and Social Sciences, 9(9), 40-54. http://dx.doi.org/10.6007/IJARBSS/v9-i9/6267

Mejah, H., Yazid, A., Bakar, A., \& Amat, S. (2020). The Provision of Tele-Counseling in Malaysia: An In-Depth Qualitative Analysis. Bisma The Journal of Counseling, 4(3), 291-298. https:// doi.org/10.23887/bisma.v4i1

Melchert, T. P., Hays, V. L., Wiljanen, L. M., \& Kolocek, A. K. (1996). Testing models of counselor development with a measure of counseling self-efficacy. Journal of Counseling \& Development, 74, 640-644. https://doi.org/10.1002/j.15566676.1996.tb02304.x

Ooi, P. B., Wan Jaafar, W. M. B., \& Baba, M. B. (2018). Relationship between sources of counseling self-efficacy and counseling self-efficacy among Malaysian school counselors. The Social Science Journal, 55(3), 369-376. https://10.1016/j.soscij.2017.05.005

Pollock, S.L. (2006). Internet counseling and its feasibility for marriage and family counseling. The Family Journal: Counseling and Therapy for Couples and Families, 14(1), 65-70. https://doi.org/10.1177/1066480705282057

Ribbers, A., \& Waringa, A. (2015). E-Coaching: Theory and practice for a new online approach to coaching. Routledge. https://doi.org/10.4324/9781315771670

Richards, D., \& Vigano, N. (2013). Online counseling: A narrative and critical review of the literature. Journal of Clinical Psychology, 69(9), 994-1011. https://doi.org/10.1002/jclp.21974

Yusof, R., Ishak, N. M., Salleh, A. M., Zahidi, A. M., \& Bakar, A. Y. A. (2017). Counseling self-efficacy (CSE) Among Malaysian School Counselors. Malaysian Online Journal of Counseling, 3(2), 73-86. University of Malaya.https://mojc.um.edu.my/index.php/MOJC/article/view/5545/3303

Salleh, A., Hamzah, R., Nordin, N., Ghavifekr, S., \& Joorabchi, T. N. (2015). Online counseling using email: a qualitative study. Asia Pacific Education Review, 16(4), 549-563. https://doi.org/10.1007/s12564-015-9393-6

Sawyer, C., Peters, M., \& Willis, J. (2013). Self-efficacy of beginning counselors to counsel clients in crisis. The Journal for Counselor Preparation and Supervision, 5(2), 30-43. https://doi.org/10.7729/52.0042.

Setiyowati, A. J., Pali, M., Wiyono, B. B., \& Triyono, T. (2019). Structural model of counseling competence. Cakrawala Pendidikan, 38(1), 45-62. https://doi.org/10.21831/cp.v38i1.21509

Skaalvik, E. M., \& Skaalvik, S. (2007). Dimensions of teacher self-efficacy and relations with strain factors, perceived collective teacher efficacy, and teacher burnout. Journal of Educational Psychology, 99(3), 611-625. https://doi.org/10.1037/00220663.99.3.611

Trepal, H., Haberstroh, S., Duffey, T., \& Evans, M. (2007). Considerations and strategies for teaching online counseling skills: Establishing relationships in cyberspace. Counselor Education and Supervision, 46(4), 266-279. https://doi.org/10.1002/j.1556-6978.2007.tb00031.x

Urbani, S., Smith, M. R., Maddux, C. D., Smaby, M. H., Torres-Rivera, E., \& Crews, J. (2002). Skills-based training and counseling self-efficacy. Counselor Education $\mathcal{E}$ Supervision, 42, 92-106. https://doi.org/10.1002/j.1556-6978.2002.tb01802.x 
Weizenbaum, J. (1966). ELIZA - A computer program for the study of natural language communication between man and machine. Communications of the ACM, 9(1), 3645. https://doi.org/10.1145/357980.357991

Wong, K. P., Bonn, G., Tam, C. L., \& Wong, C. P. (2018). Preferences for online and/or face-to-face counseling among university students in Malaysia. Frontiers in Psychology, 9, 1-5. https:// doi.org/10.3389/fpsyg.2018.00064

Zainudin, Z. N. (2006). Perhubungan Menolong Secara Maya: Satu Penelitian [Conference session]. Persidangan Lembaga Kaunselor, Hotel Legend, Kuala Lumpur, Malaysia. $\quad$ Google. GFhttps://www.google.com/url?sa=t\&rct=j\&q=\&esrc=s\&source=web\&cd=\&ca $\mathrm{d}=$ rja\&uact=8\&ved=2ahUKEwjg2pDUq7_yAhVymeYKHfQLBXsQFnoECAUQ AQ\&url=https\%3A\%2F\%2Feduc.upm.edu.my\%2Fupload\%2Fdokumen\%2Fmen ul320201222213421100percent_content_version_E-

Kaunseling_Revolusi_Teknologi_dalam_Kaunseling_pdf\&usg=AOvVaw1XHIK wB-NtVWJT4ElhhKHr

Zainudin, Z. N., Hassan, S. A., Ahmad, N. A., Yusop, Y. M., Othman, W. N. W., \& Alias, B. S. (2021). A comparison of a client's satisfaction between online and face-to-face counseling in a school setting. Pertanika Journal of Social Sciences and Humanities, 29, 135-153. https:// doi.org/10.47836/pjssh.29.s1.08

Zainudin, Z. N., \& Yusop, Y. M. (2018). Clients Satisfaction in Face-To-Face Counselling and Cyber Counseling Approaches: A Comparison. International Journal of Academic Research in Business and Social Sciences, 8(3), 677-684. https://doi.org/10.6007/ijarbss/v8-i3/3992

Zainudin, Z. N., Yusop, Y. M., Hassan, S. A., Alias, B. S. (2019). The effectiveness of cybertherapy for the introvert and extrovert personality traits. Malaysian Journal of Medicine and Health Sciences, 15, 105-109. https://medic.upm.edu.my/upload/dokumen/2019042915594715_0339(Final)1 5.pdf

Zamani, Z. A., Nasir, R., \& Yusooff, F. (2010). Perceptions towards online counseling among counselors in Malaysia. Procedia - Social and Behavioral Sciences, 5, 585-589. https://doi.org/10.1016/j.sbspro.2010.07.146 